\title{
Diagnosis of the trophism of rusty soils on the basis of soil trophic index in selected coniferous stands in the Rupin forestry in the Kurpie Plain, NE Poland
}

\author{
Sławomir Smólczyński ${ }^{1 *}$, Mirosław Orzechowski ${ }^{1}$, Monika Sięda $^{2}$ \\ ${ }^{1}$ University of Warmia and Mazury in Olsztyn, Department of Soil Science and Microbiology, Plac Łódzki 3, 10-722 Olsztyn, Poland \\ ${ }^{2}$ Graduate student \\ * Dr hab. Sławomir Smólczyński, slawomir.smolczynski@uwm.edu.pl, ORCID ID https://orcid.org: 0000-0001-7643-4284
}

\begin{abstract}
Received: 13.07.2021

Accepted: 11.12.2021

Associated editor: W. Szymański

\section{Keywords}

Rusty soils

Soil trophic index

Forest site type

Kurpie plain

The aim of the study was to compare the trophism determined on the basis of soil trophic index (SIG) of rusty soils in coniferous stands and afforested post agricultural rusty soil in the Rupin forestry. The research was carried out in the mesoregion of Kurpie Plain. The studied soils were classified as podzolic rusty soils and gleyic rusty soil. They were formed from glaciofluvial sands (sand or loamy sand) containing from $0 \%$ to $4 \%$ of clay $(<0.002 \mathrm{~mm})$ and from $2 \%$ to $17 \%$ of silt $(0.05-0.002 \mathrm{~mm})$. The $\mathrm{pH}(\mathrm{KCl})$ values of 3.9-4.2 were the lowest in the humus horizons and increased to $4.8-5.0$ in the parent material, which may indicate progressive acidification. The highest content of exchangeable hydrogen in surface horizons confirms the occurrence of this process. The organic carbon content in humus horizons amounted to $13.23-16.41 \mathrm{~g} \mathrm{~kg}^{-1}$, and total nitrogen to $0.83-1.34 \mathrm{~g} \mathrm{~kg}^{-1}$. The organic carbon to total nitrogen ratio was the narrowest in the post-agricultural Gleyic rusty soil (12-13), while in the Podzolic rusty soils it was wider and ranged from 15 to 18. Among the exchangeable cations, hydrogen dominated in the cation exchange capacity, and among the basic exchangeable cations calcium cation prevailed. The base saturation in Podzolic rusty soils ranged from 16.0 to $29.8 \%$, while in the post-agricultural Gleyic rusty soil it was the highest and was increasing down the soil profile from 35.3 to $57.1 \%$. Cation exchange capacity was positively correlated with $\mathrm{H}^{+}$and negatively with $\mathrm{pH}$ values. The numerical values of the SIG index in Podzolic rusty soils ranged from 16 to 19, which indicates oligotrophic habitats of mixed coniferous stands. The SIG index in the post-agricultural Gleyic rusty soil reached the value of 27, which indicates mesotrophic habitats of mixed broadleaved forests. The SIG values indicated a higher soil trophism than the diagnosis of the habitat trophism on the basis of the Soil and Habitats Survey - Parciaki Forest District.
\end{abstract}

\section{Introduction}

According to the Polish Soil Classification (2019) and the Classification of Polish Forest Soils (Classification ... 2000), the basic criterion for distinguishing rusty soils is the presence of siderik diagnostic horizon in the soil profile, which has the texture of sands or loamy sands. They can be of various origins, mainly fluvioglacial, as well as aeolian, boulder and weathered sands, which was confirmed by the research of numerous authors (Uggla and Ferczyńska, 1969; Uggla and Roszko, 1974; Białousz, 1978; Uggla, 1980; Bednarek, 1991; Janowska, 2001; Jankowski, 2014; Chojnicki et al., 2021a, 2021b), carried out in the areas of young and old glacial as well as in mountain areas (Szafranek, 1989; Marzec and Kabała, 2008). Rusty soils are common in the outwash plains (Bieniek, 2013; Chojnicki et al., 2021a). In northern Poland, the largest accumulation area of fluvioglacial sands is the Kurpie outwash plain, which includes the mesoregions of the Kurpie Plain and the Masurian Plain (Marks, 1990). The rusty soils of outwash plains have lower trophism (Bieniek, 2013) as well as lower genetic diversity of bacteria and enzymatic activity (Baćmaga et al., 2021), compared to brown or lessive soils of the moraine uplands. The potential range of trophism of rusty soils in forest habitats is wide, from coniferous stands to mixed broadleaved forests (Classification ... 2000), which may also pose problems with the proper use of the soils production potential (Biały, 1999; Brożek, 2007). Soil trophism is synthetically expressed by the soil trophic index (SIG), which takes into account the most important soil properties. Soil trophic index is crucial for the assessment of the production potential of soils and habitats, in the design and reconstruction of forest stands (Lasota et al., 2011a) and in forest management (Forest... 2012). It is also of great importance in the assessment of soil trophism and suitability for afforestation of post-agricultural land, which physical, chemical and biological properties are often 
significantly modified as a result of changes in use (Wanic and Błońska, 2011; Sewerniak et al., 2014; Oktaba and Kondras, 2015; Łabaz et al., 2016; Gawęda et al., 2018).

The aim of the study was to compare the trophism determined on the basis of soil trophic index (SIG) of rusty soils in coniferous stands and afforested post agricultural rusty soil in the Rupin forestry.

\section{Materials and methods}

The research was carried out in the Rupin Forestry in the Parciaki Forest District located in the Kurpie Plain mesoregion. The relief of this mesoregion was shaped by ice-melting, fluvioglacial, aeolian, and fluvial processes. The landscape of outwash plain is characterized by dunes hills, moraine outliers and moraine hills (Marks, 1990). Within the generally flat surface, there are numerous shallow depressions of various shapes and sizes, some of which filled with peat and mineral-organic sediments (Łachacz, 2001). Originally, the Kurpie Plain was covered by the Zielona Primeval Forest (Puszcza Kurpiowska) and nowadays forests in this area were changed. The Parciaki Forest District is dominated by fresh coniferous and mixed coniferous stands habitats, which constitute $67.5 \%$ of the area, while broadleaved forest habitats occupy $27.4 \%$ of the area (Forest Management Plan... 2012). The most common soils are rusty soils, which cover 51.2\%, and Podzolic soils, which cover 37.6\% of the forest district area (Soil and Habitats Survey... 2010).

\subsection{Field and laboratory methods}

For the research, post agricultural rusty soil, 40 years after afforestation and three profiles of rusty soils in nearby forest districts, which were not used for agriculture, were selected. The soil profiles were described and soil samples from each soil horizon were collected for further analyses.

The soil color was determined on the base of Standard soil color charts (Oyama and Takehara, 1992). In the collected samples, the following analyses were carried out: particle-size distribution by the laser diffraction method using Mastersizer 3000 Malvern apparatus; bulk density using $100 \mathrm{~cm}^{3}$ cylinders; organic carbon and total nitrogen contents using a CN Vario Max Cube Elementar analyzer; $\mathrm{pH}$ of soil-to-solution ratio of 1:2.5 in $\mathrm{H}_{2} \mathrm{O}$ and in $1 \mathrm{M} \mathrm{KCl}$ by the potentiometric method and the content of exchangeable base cations $\left(\mathrm{Ca}^{2+}, \mathrm{Mg}^{2+}, \mathrm{K}^{+}, \mathrm{Na}^{+}\right)$in the extract of ammonium acetate $\left(1 \mathrm{M} \mathrm{dm}^{-3}\right)$ of $\mathrm{pH}$ 7.0. Cations such as $\mathrm{Ca}^{2+}, \mathrm{Mg}^{2+}, \mathrm{K}^{+}$and $\mathrm{Na}^{+}$were measured using iCAP 7400 ICP-OES Thermo Scientific spectrometer. The content of exchangeable hydrogen was determined by the Kappen method in sodium acetate solution ( $1 \mathrm{M} \mathrm{CH}_{3} \mathrm{COONa}$ ). The cation exchange capacity (CEC), base cation exchange capacity (bCEC) and base saturation (BS) were calculated on the basis of obtained results. The results were statistically processed using the Statistica 13 software. The vegetation description in Table 3 was based on Soil and Habitats Survey - Parciaki Forest District. The values of the soil trophic index (SIG) were calculated in accordance with the methodology of Brożek at al. (2011).

\section{Results and discussion}

The studied B horizons met the criteria for the siderik soil horizon in terms of color and texture (Table 1 and 2), therefore, according to the Polish Soil Classification (2019), they were classified as rusty soils. In the soil profiles 1 and 3, very weak signs of the podzolization process were found under ectohumus, which, according to Jankowski (2014), can be described as the initial degree of podzolization. In the profile 4, the eluvial horizon was better developed - with moderate degree of podzolization of rusty soils according to Jankowski (2014). The thickness of the moder-type forest humus horizon (profiles 1, 2, 4) or moder-mor (profile 3) did not exceed $5 \mathrm{~cm}$. The studied rusty soils constituted the habitats of fresh mixed coniferous stands (profile 1 and 4), moist mixed coniferous stand (profile 2) and fresh coniferous stand (profile 3) (Table 3).

The studied soils had texture of sand and loamy sand containing from 0 to $4 \%$ of clay $(<0.002 \mathrm{~mm})$ and from 2 to $17 \%$ of silt $(0.05-0.002 \mathrm{~mm})$ (Table 1$)$. In the Gleyic rusty soil profile, below $100 \mathrm{~cm}$, loamy sand with the highest content of silt fraction (17\%) occurred.

Bulk density in humus horizons ranged between 1.280 and $1.474 \mathrm{Mg} \cdot \mathrm{m}^{-3}$, whereas in deeper horizons it was higher and ranged from 1.408 to $1.510 \mathrm{Mg} \cdot \mathrm{m}^{-3}$ (Table 2). Similar values were obtained for rusty soils of inner outwash plains by Bieniek (2013).

The studied soils were acidic. The $\mathrm{pH}(\mathrm{KCl})$ values were the lowest (3.9-4.2) in humus horizons (Table 2) and increased to 4.8-5.0 in the parent material. The organic carbon content in humus horizons ranged from 13.23 to $16.41 \mathrm{~g} \mathrm{~kg}^{-1}$, and total nitrogen from 0.83 to $1.34 \mathrm{~g} \mathrm{~kg}^{-1}$ (Table 2). The carbon to nitrogen ratio was the narrowest in the post-agricultural Gleyic rusty soil, where it amounted to 12-13, while in the Podzolic rusty soils it was wider and ranged from 15 to 18 (Table 2).

The hydrogen cation dominated among all exchangeable cations in the sorption complex of the studied soils (Table 4). The concentration of basic exchangeable cations were in the following order $\mathrm{Ca}^{2+}>\mathrm{Mg}^{2+}>\mathrm{K}^{+}$and $\mathrm{Na}^{+}$, except soil profile 3 , where $\mathrm{Na}^{+}$ prevailed over $\mathrm{Mg}^{2+}$ and $\mathrm{K}^{+}$. The BS in Podzolic rusty soils ranged from 16.0 to $29.8 \%$ (Table 4). The post-agricultural Gleyic rusty soil had the highest BS values, which increased from $35.3 \%$ in the A1 horizon to $57.1 \%$ in the C2gg horizon. The physicochemical and chemical properties of the studied soils were similar to the rusty soils studied by Uggla and Roszko (1974), Uggla, (1980, 1986), Jankowski (2014), Chojnicki at al. (2021a). According to the classification of forest soils (Classification ... 2000), the trophism of a variety of a soil subtype is determined on the base of BS values to a depth of $100 \mathrm{~cm}$. In most horizons of the studied rusty soils, the BS values were in the range of $20-50 \%$ (Table 4), which indicates mesotrophic varieties of the soil subtype, while the BS below 20\% qualifies soils as oligotrophic varieties. A similar trophism was reported for Podzolic rusty soils on the "Browsk" soil model surface in the Białowieża Primeval Forest, which were classified by Uggla (1986) as mesotrophic-oligotrophic soil varieties.

The relations between the above-described soil properties were also confirmed by the principal component analysis (Fig. 1). The first principal component PC1 explained $46.47 \%$ of 
Table 1

Particle-size distribution of the studied soils

\begin{tabular}{|c|c|c|c|c|c|c|c|c|c|c|c|}
\hline Horizon & Depth & Percent & ge content & of diamete & fractions in & $\mathrm{mm}$ & & & & Grain-size distrib & on according \\
\hline & {$[\mathrm{cm}]$} & $2.0-0.1$ & $0.1-0.05$ & $2.0-0.05$ & $0.05-0.02$ & $0.02-0.002$ & $0.05-0.002$ & $<0.002$ & $<0.02$ & PTG 2008 & USDA \\
\hline 1 Podzoli & rusty soil & $\mathrm{Vb})$ & & & & & & & & & \\
\hline $\mathrm{AE}$ & 0-18 & 85 & 8 & 93 & 4 & 2 & 6 & 1 & 3 & loose sand & sand \\
\hline $\mathrm{Bv}$ & $18-70$ & 89 & 6 & 95 & 3 & 1 & 4 & 1 & 2 & loose sand & sand \\
\hline C & $70-150$ & 95 & 3 & 98 & 1 & 1 & 2 & 0 & 1 & loose sand & sand \\
\hline 2 Gleyic $r$ & Isty soil (B & & & & & & & & & & \\
\hline Ap1 & $0-20$ & 91 & 5 & 96 & 2 & 1 & 3 & 1 & 2 & loose sand & sand \\
\hline Ap2 & $20-30$ & 93 & 3 & 96 & 3 & 1 & 4 & 0 & 1 & loose sand & sand \\
\hline $\mathrm{Bv}$ & $30-65$ & 84 & 8 & 91 & 5 & 2 & 7 & 2 & 4 & light loamy sand & sand \\
\hline C1gg & 65-100 & 93 & 1 & 94 & 3 & 2 & 5 & 1 & 3 & loose sand & sand \\
\hline C2gg & $100-150$ & 65 & 15 & 80 & 13 & 4 & 17 & 3 & 7 & loamy sand & loamy sand \\
\hline 3 Podzoli & rusty soil & $\mathrm{Vb})$ & & & & & & & & & \\
\hline $\mathrm{AE}$ & $0-16$ & 83 & 5 & 88 & 7 & 3 & 10 & 2 & 5 & light loamy sand & sand \\
\hline $\mathrm{Bv}$ & $16-60$ & 91 & 3 & 94 & 3 & 1 & 4 & 2 & 3 & loose sand & sand \\
\hline C & $60-150$ & 94 & 2 & 96 & 2 & 1 & 3 & 1 & 2 & loose sand & sand \\
\hline 4 Podzoli & rusty soil & $\mathrm{Vb})$ & & & & & & & & & \\
\hline $\mathrm{AE}$ & $0-8$ & 88 & 3 & 91 & 5 & 2 & 7 & 2 & 4 & light loamy sand & sand \\
\hline $\mathrm{ABs}$ & $8-16$ & 90 & 4 & 94 & 4 & 1 & 5 & 1 & 2 & loose sand & sand \\
\hline Bv1 & $16-29$ & 87 & 2 & 89 & 4 & 3 & 7 & 4 & 7 & light loamy sand & sand \\
\hline Bv2 & $29-65$ & 87 & 3 & 90 & 5 & 2 & 7 & 3 & 5 & light loamy sand & sand \\
\hline $\mathrm{C}$ & $65-150$ & 92 & 3 & 95 & 4 & 1 & 5 & 0 & 1 & loose sand & sand \\
\hline
\end{tabular}

Table 2

Soil physical and chemical properties

\begin{tabular}{|c|c|c|c|c|c|c|c|c|}
\hline \multirow[t]{2}{*}{ Horizon } & \multirow[t]{2}{*}{ Depth $[\mathrm{cm}]$} & \multirow{2}{*}{$\begin{array}{l}\text { Bulk density } \\
\mathrm{Mg} \cdot \mathrm{m}^{-3}\end{array}$} & \multicolumn{2}{|l|}{$\mathrm{pH}$} & \multicolumn{2}{|c|}{ Content } & \multirow[t]{2}{*}{$\mathrm{C} / \mathrm{N}$} & \multirow{2}{*}{$\begin{array}{l}\text { Soil color } \\
\text { moist soil }\end{array}$} \\
\hline & & & $\mathrm{H}_{2} \mathrm{O}$ & $\mathrm{KCl}$ & $\begin{array}{l}\mathrm{C} \\
\mathrm{g} \cdot \mathrm{kg}^{-1}\end{array}$ & $\mathrm{~N}$ & & \\
\hline \multicolumn{9}{|c|}{1 Podzolic rusty soil (BVb) } \\
\hline $\mathrm{AE}$ & $0-18$ & 1.342 & 4.6 & 4.0 & 13.23 & 0.90 & 15 & 10YR 4/1 \\
\hline $\mathrm{Bv}$ & $18-70$ & 1.471 & 5.8 & 4.6 & & & & 10YR $4 / 6$ \\
\hline $\mathrm{C}$ & $70-150$ & 1.468 & 6.0 & 4.8 & & & & 10YR $7 / 2$ \\
\hline \multicolumn{9}{|c|}{2 Gleyic rusty soil (BVgg) } \\
\hline Ap1 & $0-20$ & 1.312 & 4.8 & 4.2 & 16.41 & 1.34 & 12 & $7.5 \mathrm{YR} 4 / 1$ \\
\hline Ap2 & $20-30$ & 1.474 & 5.4 & 4.3 & 10.62 & 0.83 & 13 & 10YR 4/2 \\
\hline $\mathrm{Bv}$ & $35-65$ & 1.515 & 5.5 & 4.4 & & & & 10YR 4/4 \\
\hline C1gg & $65-100$ & 1.463 & 5.8 & 4.6 & & & & $2.5 Y 6 / 2$ \\
\hline C2gg & $100-150$ & 1.408 & 5.9 & 5.0 & & & & $5 Y 6 / 2$ \\
\hline \multicolumn{9}{|c|}{3 Podzolic rusty soil (BVb) } \\
\hline $\mathrm{AE}$ & $0-16$ & 1.305 & 4.4 & 3.9 & 15.22 & 0.85 & 18 & 10YR 5/2 \\
\hline $\mathrm{Bv}$ & $16-60$ & 1.486 & 5.4 & 4.7 & & & & 10YR 6/8 \\
\hline $\mathrm{C}$ & $60-150$ & 1.420 & 5.7 & 4.8 & & & & $7.5 \mathrm{YR} 8 / 2$ \\
\hline \multicolumn{9}{|c|}{4 Podzolic rusty soil (BVb) } \\
\hline $\mathrm{AE}$ & $0-8$ & 1.280 & 4.6 & 4.0 & 13.97 & 0.91 & 15 & 10YR 4/1 \\
\hline ABs & $8-16$ & 1.440 & 5.3 & 4.4 & & & & 10YR 4/3 \\
\hline Bv1 & $16-29$ & 1.465 & 5.7 & 4.8 & & & & 10YR 5/8 \\
\hline Bv2 & $29-65$ & 1.510 & 5.8 & 4.9 & & & & 10YR 4/6 \\
\hline $\mathrm{C}$ & $65-150$ & 1.482 & 5.9 & 4.9 & & & & $2.5 Y 7 / 1$ \\
\hline
\end{tabular}


Table 3

Forest habitat types and vegetation at the studied sites

\begin{tabular}{|c|c|c|}
\hline Profile & Forest floor vegetation & Stand \\
\hline \multirow[t]{2}{*}{1} & BMśw Fresh mixed coniferous forest & Age: 30 years \\
\hline & $\begin{array}{l}\text { Carex nigra Reichard, Trientalis europaea (L.), } \\
\text { Majanthemum bifolium (L.), Veronica officinalis (L.), } \\
\text { Convallaria majalis (L.,) Hylocomium splendens (Hedw) }\end{array}$ & $\begin{array}{l}\text { Pinus silvestris (L.), Betula pendula Roth. } \\
\text { in the undergrowth Sorbus aucuparia (L.), Corylus avellana (L.), } \\
\text { Frangula alnus Mill, }\end{array}$ \\
\hline \multirow[t]{2}{*}{2} & BMw Moist mixed coniferous forest site & Age: 40 years \\
\hline & $\begin{array}{l}\text { Molinia caerulea (L.), Lysimachia vulgaris (L.), } \\
\text { Trientalis europaea (L.), Pteridium aquilinum (L.), } \\
\text { Carex nigra Reichard, Potentilla erecta (L.) }\end{array}$ & $\begin{array}{l}\text { Pinus silvestris (L.), Betula pendula Roth. } \\
\text { Populus tremula (L.), } \\
\text { in the undergrowth Sorbus aucuparia (L.), Corylus avellana (L.), } \\
\text { Frangula alnus Mill, }\end{array}$ \\
\hline \multirow[t]{2}{*}{3} & Bśw Fresh coniferous forest & Age: 70 years \\
\hline & $\begin{array}{l}\text { Vaccinium myrtillus (L.), Hylocomium splendens (Hedw.), } \\
\text { Luzula pilosa (L.), Convallaria majalis (L.), } \\
\text { Vaccinium vitis-idaea (L.), Dicranum scoparium (L.), } \\
\text { Dicranum polysetum (L.) }\end{array}$ & $\begin{array}{l}\text { Pinus silvestris (L.). Betula pendula Roth. } \\
\text { in the undergrowth Sorbus aucuparia (L.), Picea abies (L.), } \\
\text { Frangula alnus Mill, Quercus petraea (Matt.) }\end{array}$ \\
\hline \multirow[t]{2}{*}{4} & BMśw Fresh mixed coniferous forest & Age: 80 years \\
\hline & $\begin{array}{l}\text { Vaccinium myrtillus (L.), Dicranum polysetum (L.), } \\
\text { Hylocomium splendens (Hedw.), Leucobryum glaucum (Hedw.), } \\
\text { Melampyrum pratense (L.), Calluna vulgaris (L }\end{array}$ & $\begin{array}{l}\text { Pinus silvestris (L.) } \\
\text { Betula pendula Roth. } \\
\text { admixture of Picea abies (L.), } \\
\text { in the undergrowth Sorbus aucuparia (L.), Juniperus communis (L.), } \\
\text { Frangula alnus Mill, Sambucus nigra (L.) }\end{array}$ \\
\hline
\end{tabular}

Table 4

Sorptive properties of the studied soils

\begin{tabular}{|c|c|c|c|c|c|c|c|c|c|}
\hline Horizon & $\begin{array}{l}\text { Depth } \\
\text { [cm] }\end{array}$ & \multicolumn{7}{|c|}{$\mathrm{cmol}_{(+)} \mathrm{kg}^{-1}$ of soil } & $\begin{array}{l}\text { BS } \\
\%\end{array}$ \\
\hline \multicolumn{10}{|c|}{1 Podzolic rusty soil (BVb) } \\
\hline $\mathrm{AE}$ & $0-18$ & 1.68 & 0.42 & 0.31 & 0.26 & 8.30 & 2.67 & 10.97 & 24.4 \\
\hline $\mathrm{Bv}$ & $18-70$ & 0.87 & 0.30 & 0.20 & 0.24 & 4.41 & 1.61 & 6.02 & 26.7 \\
\hline C & $70-150$ & 0.44 & 0.25 & 0.16 & 0.14 & 2.20 & 0.99 & 4.19 & 23.6 \\
\hline \multicolumn{10}{|c|}{2 Gleyic rusty soil (BVgg) } \\
\hline Ap1 & $0-20$ & 2.21 & 0.88 & 0.40 & 0.34 & 7.02 & 3.83 & 10.85 & 35.3 \\
\hline Ap2 & $20-35$ & 1.80 & 0.36 & 0.22 & 0.21 & 4.18 & 2.59 & 6.77 & 38.3 \\
\hline $\mathrm{Bv}$ & $35-60$ & 2.36 & 0.56 & 0.30 & 0.40 & 5.10 & 3.62 & 8.72 & 41.5 \\
\hline C1gg & $60-100$ & 1.55 & 0.45 & 0.14 & 0.15 & 3.09 & 2.29 & 5.38 & 42.6 \\
\hline C2gg & $100-150$ & 3.10 & 0.80 & 0.25 & 0.23 & 3.30 & 4.39 & 7.69 & 57.1 \\
\hline \multicolumn{10}{|c|}{3 Podzolic rusty soil (BVb) } \\
\hline $\mathrm{AE}$ & $0-16$ & 1.24 & 0.12 & 0.16 & 0.22 & 8.50 & 1.74 & 9.24 & 18.8 \\
\hline $\mathrm{Bv}$ & $16-60$ & 0.77 & 0.10 & 0.10 & 0.12 & 3.81 & 1.09 & 4.90 & 22.2 \\
\hline C & $60-150$ & 0.52 & 0.08 & 0.08 & 0.14 & 1.40 & 0.82 & 3.22 & 25.5 \\
\hline \multicolumn{10}{|c|}{4 Podzolic rusty soil (BVb) } \\
\hline $\mathrm{AE}$ & $0-8$ & 2.60 & 0.86 & 0.34 & 0.20 & 9.80 & 4.00 & 13.8 & 27.0 \\
\hline ABs & $8-16$ & 0.89 & 0.32 & 0.20 & 0.17 & 7.28 & 1.58 & 8.86 & 16.0 \\
\hline Bv1 & $16-29$ & 1.14 & 0.41 & 0.22 & 0.25 & 4.60 & 2.02 & 6.62 & 26.5 \\
\hline Bv2 & $29-65$ & 1.02 & 0.40 & 0.14 & 0.22 & 3.20 & 1.78 & 4.98 & 29.8 \\
\hline C & 65-150 & 0.68 & 0.26 & 0.10 & 0.12 & 2.40 & 1.16 & 3.56 & 25.4 \\
\hline
\end{tabular}

TEB - total exchangeable base cations, BS - base saturation, CEC - cation exchange capacity 
the total variability of data, and the second principal component PC2, explained $26.38 \%$ of the total variance. The PC1 was negatively correlated with sand $(-0.720)$ and positively correlated with silt fraction (0.701), $\mathrm{Ca}^{2+}(0.934), \mathrm{Mg}^{2+}(0.833), \mathrm{K}^{+}(0.793)$, TEB (total exchangeable base cations) (0.941), BS (0.734). PC2 was positively correlated with $\mathrm{H}^{+}(0.892)$, CEC (0.835) and negatively correlated with $\mathrm{pH} \mathrm{H}_{2} \mathrm{O}(-0.855)$ and $\mathrm{pH} \mathrm{KCl}(-0.757)$.

Soil properties such as TEB, $\mathrm{K}^{+}, \mathrm{Ca}^{2+}, \mathrm{Na}^{+}, \mathrm{Mg}^{2+}$ are positively correlated with silt and clay fractions and negatively correlated with sand fraction. CEC was positively correlated with $\mathrm{H}^{+}$and negatively with $\mathrm{pH}$ values (Fig. 1).

The numerical values of the SIG index in Podzolic rusty soils ranged from 16 to 19 (Table 5), which according to the Forest Management Instruction (Forest ... 2012) indicates oligotrophic habitats of mixed coniferous stands, which was consistent with the diagnosis based on the undergrowth vegetation in the case of profiles 1 and 4 (Table 3). On the other hand, in the case of Podzolic rusty soils (profile 3), there is a discrepancy between the diagnosis of the habitat by the forest stand and undergrowth (Table 3) and the diagnosis based on the SIG, which indicates a higher soil trophism (Table 5). The inconsistency confirms the thesis of underestimating the production potential of rusty soils in forest habitats (Biały, 1999). The highest trophism was noted for post-agricultural soil, in which the SIG index reached the value of 27, which indicates mesotrophic habitat of mixed broadleaved forests (Forest ... 2012). On this soil, also species characteristic of forests, e.g. Corylus avellana (L.) in the undergrowth and Lysimachia vulgaris (L.) in the forest floor (Table 3) were growing, which confirms the correctness of the diagnosis of soil trophism determined on the basis of SIG. Among the SIG partial indices, the highest values were obtained for the WS index (value of the base cations) of 7-9 (Table 5). In Podzolic rusty soils, the WY (value of the acidity recalculated) (value of 1-3) and the content of fraction $<0.02 \mathrm{~mm}$ (value of 2-4) was the lowest (Table 5), which results from high acidity of humus horizons, sandy texture and low content of fraction $<0.02 \mathrm{~mm}$. Chojnicki (2020) indicated that due to the excessively high proportion of pine stands, the soils become acidified, which leads to a reduction in trophism. Uggla and Roszko (1974) emphasized, however, that with the absence or low content of fraction $<0.02 \mathrm{~mm}$, silt and fine sand play an essential role in shaping the water conditions. Considering the trophism, important is the mineral composition of coarse fractions, which is a derivative of their genesis (Białousz, 1978). The research carried out by Uggla and Roszko (1974) showed that in rusty soils the differences in the content of easily weathered minerals between the sands from outwash

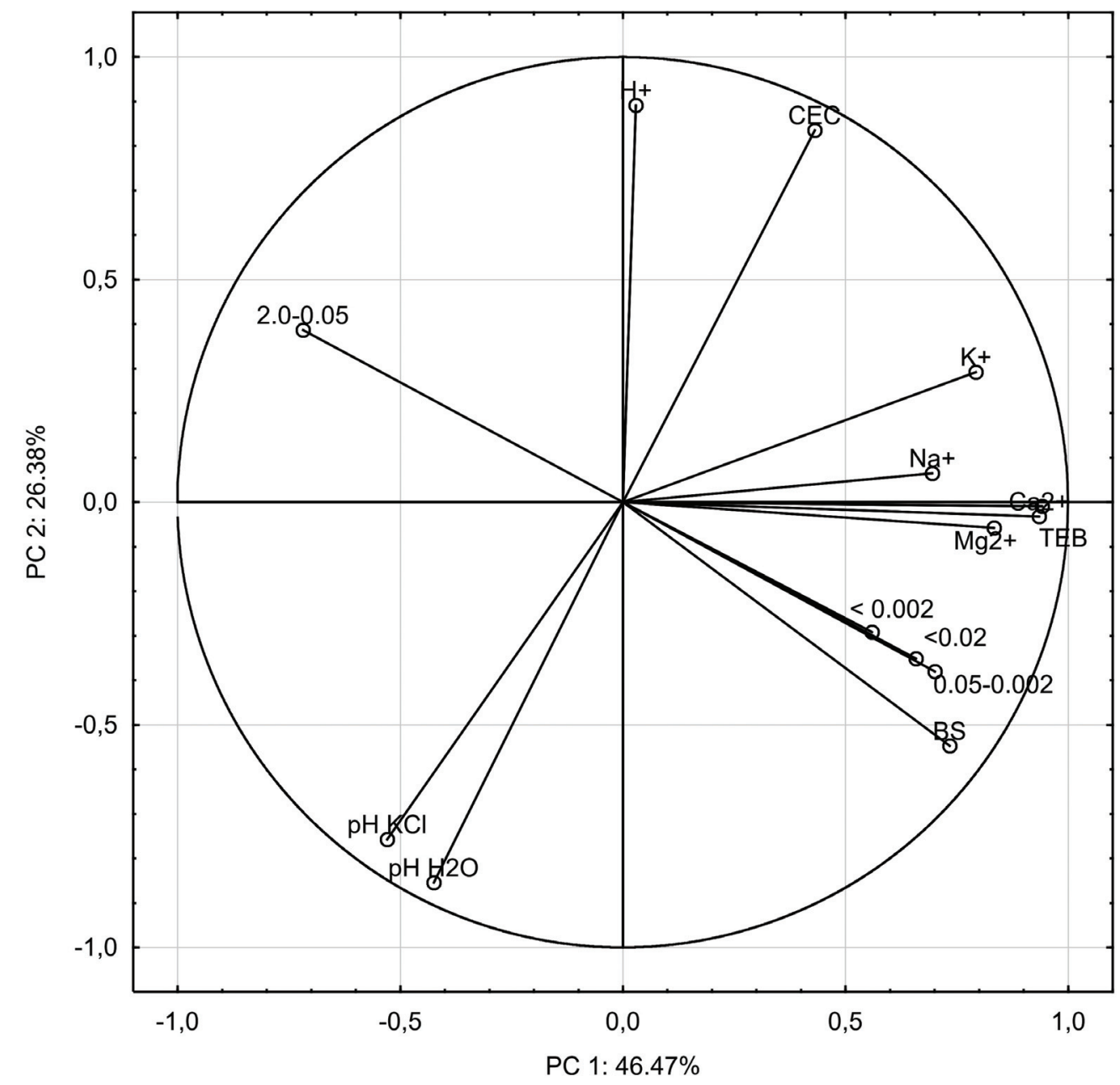

Fig. 1. Principal component analysis of the studied soil properties 
Table 5.

Partial indicators of soil trophic index SIG and partial values of soil trophic index and diagnosis of trophic status

\begin{tabular}{|c|c|c|c|c|c|c|c|c|}
\hline Soil profile & & WCZS & WS & WY & WN & SIG & Trophic status & Forest site types* \\
\hline \multirow[t]{2}{*}{1 Podzolic rusty soil (BVb) } & indicators & 2 & 8 & 1 & 5 & 16 & oligotrophic & $\mathrm{BM}$ \\
\hline & values & 34 & 30.4 & 2.322 & 0.006 & & & \\
\hline \multirow[t]{2}{*}{2 Gleyic rusty soil (BVgg) } & indicators & 5 & 9 & 5 & 8 & 27 & mezotrophic & LM \\
\hline & values & 85 & 61.8 & 0.769 & 0.012 & & & \\
\hline \multirow[t]{2}{*}{3 Podzolic rusty soil (BVb) } & indicators & 4 & 7 & 3 & 4 & 18 & oligotrophic & $\mathrm{BM}$ \\
\hline & values & 55 & 21.2 & 1.089 & 0.005 & & & \\
\hline \multirow[t]{2}{*}{4 Podzolic rusty soil (BVb) } & indicators & 4 & 8 & 2 & 5 & 19 & oligotrophic & $\mathrm{BM}$ \\
\hline & values & 59 & 34.1 & 1.257 & 0.006 & & & \\
\hline
\end{tabular}

WCZS - value of the content of fraction $<0.02 \mathrm{~mm}$, WS - value of the base cations, WY - value of the acidity recalculated, WN - value of nitrogen recalculated, the latter only for topsoil horizon, *forest site types - according SIG, BM - mixed coniferous forest site, LM - mixed broadleaved forest site

plains and moraines may be up to $20 \%$. In the post-agricultural Gleyic rusty soil, a high valorization, in addition to the value of the base cations (WS of 9), was achieved by the value of nitrogen WN (value of nitrogen recalculated, the latter only for topsoil horizon), which reached 8 (Table 5). According to Wanic and Błońska (2011), the SIG index calculated for post-agricultural soils also includes, to some extent, soil trophism modifications caused by agricultural activities, e.g. fertilization. Łabaz at al. (2016) indicated that the SIG index in post-agricultural soils does not take into account the thickness of humus horizon as well as carbon and nitrogen stocks, which, according to these authors, constitute a useful long-term reserve for soil fauna and plant communities.

The range of trophism, similar to the one reported for studied rusty soils in the Kurpie Plain, numerically expressed by the SIG index (16-27), was also observed in the research of analogous soils in forest habitats of various regions in Poland (Lasota et al., 2011b; Chojnicki, 2020; Chojnicki et al., 2021b).

The research carried out at 122 study sites by Brożek et al. (2008), showed great variability in trophism of various subtypes of rusty soils, from dystrophic to eutrophic, in which the values of SIG ranged from 8 to 33. Most of the profiles of podzolic rusty soils studied by these authors were classified as oligotrophic (SIG values 11-20). Brożek et al. (2008) reported that in the group of podzolic rusty soils, in which the SIG values amounted to 16-19, similarly to the results obtained in this study, the identification of the habitat according to forest floor vegetation and forest stand consistently indicated the mixed coniferous stand. The values of the WCZS (value of the content of fraction $<0.02 \mathrm{~mm}$ ), WS, WY, WN for the studied soils, included in the equation of SIG, were similar to the values reported by Lasota et al. (2011b). It should be emphasized that the appropriate (correct) determination of the trophism of the soil and the type of forest habitat is of key importance not only for the use of forest production potential but also for prevention of soil degradation. The studies of Biały (1999) and Jankowski (2014) indicated that the introduction of pine stands led to soil degradation and development of podzolic process. Sewerniak et al. (2014) indicated that in the profiles of post-agricultural soils, 20 years after afforestation, under pine stands, morphological changes in the soil profile, manifested in the accumulation of forest humus (forest litter), were observed, as well as signs of the podzolic and acidification processes. The progressive acidification had serious consequences in determination of the habitat trophism on the basis of soil properties, as it led to the reduction of SIG values. Sewerniak (2020) provides strong arguments to increase species richness, especially on rusty soils, what is crucial for the functioning of forest ecosystems, related to high plant biodiversity and efficient nutrient turnover, and which may be more important for forest productivity than soil fertility. The location of tree stands in land relief is of great importance at sandy areas (Sewerniak, 2016).

\section{Conclusions}

The studied rusty soils were classified as Podzolic rusty soils and Gleyic rusty soils (post-agricultural soil), which were formed from glaciofluvial sands exhibiting sandy or loamy sandy texture. The soils were acidic and the BS in Podzolic rusty soils ranged from 16.0 to $29.8 \%$, while in the post-agricultural Gleyic rusty soil it ranged from 35.3 to $57.1 \%$. In studied soils the progressive acidification occurs.

The numerical values of the SIG index in Podzolic rusty soils ranged from 16 to 19, which indicates oligotrophic habitats of mixed coniferous stands. The highest values of the SIG (27) index were achieved in the post-agricultural Gleyic rusty soil, which indicates mesotrophic habitats of mixed broadleved forests. Among the SIG partial indices in Podzolic rusty soils, the value of the acidity and value of the content of fraction $<0.02 \mathrm{~mm}$ were rated the lowest. It was observed that SIG values at two sites indicated higher soil trophism in relation to the diagnosis of the habitat trophism on the basis of the Soil and Habitats Survey - Parciaki Forest District.

\section{Acknowledgments}

The results presented in this paper were obtained as part of a comprehensive study financed by University of Warmia and Mazury in Olsztyn, Faculty of Agriculture and Forestry, Department of Soil Science and Microbiology (No 30.610.005-110). 


\section{References}

Baćmaga, M., Wyszkowska, J., Borowik, A., Kucharski, J., Paprocki, Ł., 2021. Microbiological and biochemical properties in Eutric/Dystric Brunic Arenosols, Eutric/Endocalcaric Cambisols, and Haplic/Albic Luvisols Soils. Journal of Soil Science and Plant Nutrition 21, 12771292. https://doi.org/10.1007/s42729-021-00439-7.

Bednarek, R., 1991. Age, genesis and systematic position of rusty soils in the light of palaeopedological research in the vicinity of Osja. UMK, Torun.

Białousz, S., 1978. The influence of morphogenesis of Mazurian Lakeland on the development of soils. Wpływ morfogenezy Pojezierza Mazurskiego na kształtowanie się gleb. Rocz. Nauk Rol., D-166, 87-126.

Biały, K., 1999. Optionality in discrimination of forest site types and planning final species compositions in stand on podzolic soils. Sylwan 143(5), 65-72.

Bieniek, A., 2013. Soils of inner outwash in the North-Eastern Poland. Rozprawy i monografie 184. Wydawnictwo UWM w Olsztynie.

Brożek, S., 2007. Classification of forest habitats - comments on the position of soils in the principles of diagnosis. Sylwan 151(2), 19-25.

Brożek, S., Zwydak, M., Lasota, J., 2008. Numerical index of trophic varieties of podzolic and rusty soils. Roczniki Gleboznawcze - Soil Science Annual 59(1), 1-17.

Brożek, S., Zwydak, M., Lasota, J., Różanski, W., 2011. Methodical approach to research on the relations between plant communities and soil in forests. Roczniki Gleboznawcze - Soil Science Annual 62(4), 16-38.

Chojnicki, J., 2020. Evaluation of the trophism of soils in the 'Rybitew' strict protection area in the Kampinos National Park based on the soil trophic index. Sylwan 164(9), 758-766. https://doi.org/10.26202/ sylwan.2020056.

Chojnicki, J., Kwasowski, W., Wójcik, R., 2021a. Assessment of the function and destination of the Soil Model Area in the Puszcza Biała depending on the typology and properties of soils. Sylwan 165(3), 223-232. https://doi.org/10.26202/sylwan.2020115.

Chojnicki, J., Kwasowski, W., Zielony, R., 2021b. Assessment of the function and destination of the Soil Model Area in the Puszcza Biała Forest depending on the diagnosis of forest site. Sylwan 165(4), 296-304, https://doi.org/10.26202/sylwan.2020124.

Classification of forest soils in Poland. 2000. CILP, Warszawa.

Forest Equipment Plan. Parciaki Forest District. 2012. Wydawnictwo Biuro Urządzania Lasu i Geodezji Leśnej Oddział w Olsztynie, Olsztyn.

Forest management instructions. 2012. Part II. Instructions for distinguishing and mapping forest habitat types and plant communities in the State Forests. CILP, Warszawa.

Gawęda, T., Błońska, E., Małek, S., Bijak, S., Zasada, M., 2018. Application of ITGL in the assessment of post-agricultural soils with natural regeneration of silver birch. Sylwan 162(5), 396-402. https://doi. org/10.26202/sylwan.2017140.

Jankowski, M., 2014. Podzolization as a secondary process in the rusty soils of the Brodnica Landscape Park. [In:] Świtoniak, M., Jankowski, M., Bednarek, R. (Eds.), Anthropogenic transformations of the soil cover of the Brodnica Landscape Park. Wydawnictwo Naukowe Uniwersytetu Mikołaja Kopernika. Toruń, 9-24.

Janowska, E., 2001. Origin and properties of rusty soils in the area of the central polish glaciation. Wydawnictwo SGGW Warszawa.

Lasota, J., Brożek, S., Zwydak, M., 2011a. Application of the trophic soil index in planning the composition of renewed forest stands. Roczniki Gleboznawcze - Soil Science Annual 62(4), 150-162.

Lasota, J., Zwydak, M., Wanic, T., Brożek, S., 2011b. Soil diversity of mixed coniferous forest communities. Roczniki Gleboznawcze - Soil Science Annual 62(4), 54-72. (in Polish with English abstract)
Łabaz, B., Kabała, C., Bogacz, A., 2016. Problems of trophic status diagnosis in the forest habitats on former arable alluvial soils. Sylwan 160(8), 684-695. https://doi.org/10.26202/sylwan.2016020.

Łachacz, A., 2001. Origin and properties of shallow organogenic soils of the Mazury and Kurpie outwash plain. Wydawnictwo UWM w Olsztynie.

Marks, L., 1990. Outline of the geological structure of the evolution of the north-western part of the Kurpie outwash plain. Kwartalnik Geologiczny 34(3), 489-502.

Marzec, M., Kabała, C., 2008. Brunic regosols and dystric cambisols developed of granite regolithes in the sudety mountains - morphology, properties and classification. Roczniki Gleboznawcze - Soil Science Annual 59(3/4), 195-205. (in Polish with English abstract)

Oktaba, L., Kondras, M., 2015. Organic matter transformation in meadow soils during the first years after afforestation. Sylwan 159(2), 126-134. https://doi.org/10.26202/sylwan.2014074.

Oyama, M., Takehara, M., 1992. Revised standard Munsell soil color charts. Tokio.

Particle size distribution and textural classes of soils and mineral materials - classification of Polish Society of Soil Science 2008. Roczniki Gleboznawcze - Soil Science Annual 60(2), 5-16.

Polish Soil Classification (Systematyka Gleb Polski), 2019. Soil Science Society of Poland, Commission on Soil Genesis, Classification and Cartography. Wydawnictwo Uniwersytetu Przyrodniczego we Wrocławiu, Polskie Towarzystwo Gleboznawcze, Wrocław - Warszawa.

Sewerniak, P., Sylwestrzak, K., Bednarek, R., Gonet, S., 2014. Post-agricultural soils in forests. [In:] Świtoniak, M., Jankowski, M., Bednarek, R. (Eds.), Anthropogenic transformations of the soil cover of the Brodnica Landscape Park. Wydawnictwo Naukowe Uniwersytetu Mikołaja Kopernika. Toruń, 44-56.

Sewerniak, P., 2016. Impact of land relief on site index and growth parameters of Scots pine stands on inland dunes in the Torun Basin. Wpływ rzeźby terenu na bonitację i cechy wzrostowe drzewostanów sosnowych na wydmach Kotliny Toruńskiej. Sylwan 160(8), 647-655,

Sewerniak, P., 2020. Plant species richness or soil fertility: which affects more the productivity of Scots pine in Central Europe? Annals of Forest Research 63(2), 57-73. https://doi.org/10.15287/afr.2020.2003.

Soil and Habitats Survey - Parciaki Forest District. 2010. Wydawnictwo Biuro Urządzania Lasu i Geodezji Leśnej, Gdynia.

Szafranek, A., 1989. The effect of the area relief and the parent rock on formation of soils developed from Devonian and Triassic sandstones of the Świętokrzyski region. Roczniki Gleboznawcze - Soil Science Annual 40(2), 59-81. (in Polish with English abstract)

Uggla, Z., 1980. A study of the soils of plant communities in pine forests of Olsztyn Lakeland. Zeszyty Naukowe Akademii Rolniczo-Technicznej w Olsztynie 9, 3-68.

Uggla, H., 1986. Soil studies in Division 165 of the Browsk Forest District in the Białowieża Primeval Forest. Acta Academiae Agriculturae ac Technicae Olstenensis 287, Geodaesia et Ruris Regulatio 16, 13-30.

Uggla, H., Ferczyńska, Z., 1969. Soil relations in a catena of „Kudypy” coniferous habitat. Stosunki glebowe w katenie siedlisk borowych „Kudypy”. Zeszyty Naukowe Wyższej Szkoły Rolniczej w Olsztynie 25(709), 719-737.

Uggla, H., Roszko, H., 1974. Preliminary studies on rusty soils (ochric soils) in coniferous forests in the Szczytno district. Sylwan 10, 25-35.

Wanic, T., Błońska, E., 2011. Zastosowanie metody SIG w ocenie przydatności terenów porolnych do hodowli lasu. Roczniki Gleboznawcze - Soil Science Annual 62(4), 173-181. 
Diagnoza trofizmu gleb rdzawych na podstawie siedliskowego indeksu glebowego w wybranych siedliskach borowych w leśnictwie Rupin na Równinie Kurpiowskiej

\section{Słowa kluczowe}

Gleby rdzawe

Siedliskowy indeks glebowy

Typ siedliskowy lasu

Równina Kurpiowska

\section{Streszczenie}

Celem pracy było porównanie trofizmu określonego na podstawie siedliskowego indeksu glebowego, gleb rdzawych w dominujących siedliskach borowych w leśnictwie Rupin z zalesioną glebą rdzawą porolną. Badania przeprowadzono na terenie Nadleśnictwa Parciaki zlokalizowanym w Mezoregionie Równiny Kurpiowskiej. Badane gleby określono jako gleby rdzawe zbielicowane oraz gleby rdzawe gruntowo-glejowe. Wytworzyły się one z piasków luźnych i słabo gliniastych o zawartości frakcji iłowej $(<0.002 \mathrm{~mm})$ od 0 do $4 \%$ i pyłowej $(0.05-0.002 \mathrm{~mm})$ od 2 do $17 \%$. Odczyn badanych gleb był kwaśny. Wartości pH zmierzone w roztworze $1 \mathrm{M} \mathrm{KCl} \mathrm{najniższe} \mathrm{były} \mathrm{w} \mathrm{wierzch-}$ nich poziomach próchnicznych 3.9-4.2 i zwiększały się wraz z głębokością profilu do 4.8-5.0 w materiale macierzystym, co może świadczyć o zachodzącym procesie zakwaszenia. Proces ten potwierdza najwyższa zawartość wodoru wymiennego w poziomach wierzchnich. Zawartość węgla organicznego w poziomach próchnicznych wynosiła 13.23-16.41 g·kg-1 a azotu ogólnego $0.83-1.34 \mathrm{~g} \cdot \mathrm{kg}^{-1}$. Stosunek węgla do azotu najwęższy był w porolnej glebie rdzawej gruntowo-glejowej (12-13) natomiast w glebach rdzawych zbielicowanych był szerszy i wahał się od 15 do 18. Spośród kationów wymiennych w kompleksie sorpcyjnym badanych gleb dominował wodór, natomiast wśród zasadowych kationów wymiennych dominował kation wapnia. Stopień wysycenia kompleksu sorpcyjnego kationami zasadowymi w glebach rdzawych zbielicowanych wahał się od 16.0 do 29.8\% natomiast w glebie porolnej był najwyższy i zwiększał się wraz z głębokością profilu od 35.3 do 57.1\%. Wartości liczbowe wskaźnika SIG w glebach rdzawych zbielicowanych wynosiły od 16 do19, co wskazuje na siedliska oligotroficzne borów mieszanych. Wskaźnik SIG w glebie rdzawej gruntowo-glejowej, porolnej osiągnął wartość 27, co wskazuje na siedliska mezotroficzne lasów mieszanych. Stwierdzono, że wartości SIG wskazują na wyższy trofizm gleb w stosunku do trofizmu określonego w Operacie Glebowo - Siedliskowym Nadleśnictwa Parciaki. 